\title{
МЕТОДОЛОГІЧНЕ ЗАБЕЗПЕЧЕННЯ В НАВЧАЛЬНОМУ ПРОЦЕСІ ПІСЛЯДИПЛОМНОЇ ОСВІТИ ЛІКАРІВ-СТОМАТОЛОГІВ-ІНТЕРНІВ
}

\author{
М. М. Рожко, Л. І. Пелехан, С. В. Косенко, Н. М. Павелко, О. Б. Сорока, \\ Н. І. Музиченко, 3. Т. Костишин, Н. С. Іванова, О. М. Ільницька \\ Івано-Франківський національний медичний університет
}

\section{METHODOLOGICAL SUPPORT IN THE EDUCATIONAL PROCESS OF POST-GRADUATE EDUCATION OF DOCTORS-STOMATOLOGISTS INTERNS}

\author{
M. M. Rozhko, L. I. Pelehan, S. V. Kosenko, N. M. Pavelko, O. B. Soroka, \\ N. I. Muzychenko, Z. T. Kostyshyn, N. S. Ivanova, O. M. Inytska \\ Ivano-Frankivsk National Medical University
}

\begin{abstract}
Дане повідомлення є продовженням аналізу та спостережень у серії наукових робіт педагогічного спрямування співробітників кафедри стоматології ФПО ДВНЗ “ІФНМУ”. Присвячено оптимізації навчального процесу при підготовці фахівців за спеціальністю “Стоматологія". Методологічне забезпечення процесу навчання лікарів-інтернів-стоматологів шляхом застосування засобів (у вигляді методик) та заходів (у вигляді процесу організації) навчання приводить до підвищення ефективності якості навчання значної кількості тих, хто навчається. Результативність навчання, що проаналізована протягом 2007 - 2012 років при підготовці фахівців за спеціальністю “Стоматологія" представлена у вигляді діаграм. Результати роботи свідчать про те, що організаційні заходи, проведені на кафедрі, сприяли ефективному впровадженню засобів навчання, таких' як методики навчання.
\end{abstract}

This message is the continuation of the analysis and observations in a series of scientific research works with a pedagogical direction of the Dental Department staff of FPGE of SHEI «IFNMU». It is devoted to help the optimization of the post-graduate training of dentists. Methoddogical support of educational process of doctors-interns-stomatologists by using the means (in the form of methods) and measures (in the form of organizational process) of studies, leads to efficiency increase of studies quality of those who study. All results for the academic years 2007 and 2012 are represented in the form of diagrams and the optimization process in the form of a chart. Results of this works prove that organizational methods in use by the teaching staff of the Dental Departament helped to introduce new effective methods of teaching.

Вступ. Вища освіта як педагогічна система є багатофункціональною і багатоступеневою. Вона включає змістовний, організаційний і методичний компоненти. Вважають, що сучасна педагогіка - це комплекс теоретичних і прикладних наук про навчання, виховання і освіту як спеціально організовані і цілеспрямовані процеси, а також шляхи удосконалення цих процесів [3]. У законі “Про вищу освіту” (2002) вищу освіту визнано як "рівень освіти, який здобувається особою у вищому навчальному закладі в результаті послідовного, системного та цілеспрямованого процесу засвоєння змісту навчання... й завершується здобуттям певної кваліфікації за підсумками державної атестаціі”. Педагогіка вищої школи може розглядатися як елемент культури викладача вищого навчального закладу. Педагогіку вищої школи вважають наукою та мистецтвом. Як кожна наука, педагогіка вищої школи має свій категоріально- понятійний апарат. Педагоги В. М. Галузинський, М. В. Євтух поділяють категорії на три види: методологічні, процесуальні та суттєві. До методологічних відносять: педагогічні теорії, педагогічні концепщії, педагогічні ідеї, педагогічні закономірності [1].

У даному повідомленні буде розглянуто процес перетворення видів категоріально-понятійного апарату вищої школи, а саме - педагогічної ідеї в педагогічну концепцію. Педагогічна ідея - це новий напрям думки, твердження або розгорнута модель, що відображає ті чи інші зв' язки у вузівській дійсності. Педагогічна концепція - система критичних поглядів на реальну вузівську дійсність і відповідність пошуку та пропозиції нових конструктивних ідей [4].

Основна частина. Метою нашої роботи був аналіз результатів професійного навчання за системою “Крок 3. Стоматологія" лікарів-інтернів-стоматологів при впровадженні засобів та заходів навчання, зав-

(с) М. М. Рожко, Л. І. Пелехан, С. В. Косенко та ін. 
дяки яким формуються не тільки навички вирішування тестових завдань, але і навички самостійної діяльності за галузевими стандартами. Матеріалами досліджень були кафедральні архівні дані результатів іспиту “Крок 3. Стоматологія” протягом 20072012 років, що піддавалися статистичній обробці. При аналізі результатів використовували діахронічний (історичний) метод досліджень.

У процесі аналізу були висвітлені та окреслені найбільш вагомі складові проблем навчального процесу, що мали місце на кафедрі стоматології ФПО ДВНЗ "ІФНМУ” при підготовці лікарів-інтернів-стоматологів, оскільки навчання в інтернатурі має очний та заочний цикли. Завдання, які стояли перед нами, зводилися до наступного: задіяти ресурсний потенціал оптимізації навчального процесу за межами матеріальної бази кафедри; використати з білышою віддачею в процесі педагогічної діяльності той ресурсний потенціал, яким володіє кафедра. Під ресурсами розуміли ті об' єктивні складові будь-якої діяльності, без яких неможлива діяльність суспільства. Було проаналізовано адміністративні, кадрові, матеріальні, інноваційні, інформаційні та фінансові складові, активізація яких здатна привести до покращення результатів навчання.

У результаті аналізу висунута педагогічна ідея оптимізації процесу навчання. Відомо, що набуваючи самостійного характеру, ідеї можуть поєднуватися у концепції, частково слугуючи поповненням теорії. Педагогічна ідея мала у своій сутності посилення самостійності у навчанні інтернів-стоматологів. Об'єднуючись з іншими закономірностями вузівської дійсності з урахуванням самостійності студентів, ідея набула концептуального характеру. Оптимізація навчального процесу може відбутися тільки за умов застосування викладачем нових технологій навчання, що спонукають до мотивованих дій того, хто навчається. I, навпаки, використання архаїчних методик гальмує розвиток того, хто навчається.

Алгоритм методики складався із таких етапів, як:

I eman - загального фахового орієнтування (ознайомлення із журналом обліку роботи лікаря-інтернастоматолога-щоденником, заповнення його розділів, системне сприйняття діяльності за фахом, констатація протиріч навчання);

II етаn - визначення вихідного рівня знань ("Пробний Крок 3", аналіз власної освіти за об'єктивно отриманим фактичним відсотком, орієнтування на виконання відповідних видів робіт);

III eman - виконавча частина (читання лекцій, ведення практичних занять та семінарів з метою оптимізації засвоєння фактичного матеріалу);
IV eman - констатація протиріч у визначенні елементів персональної власної оцінки у системі знань, умінь та навичок (суб'єктивна та об'єктивна система оцінки отриманих ділових робочих стосунків, знань, умінь та навичок, виявлення найслабкіших відділків у системі власної освіти);

V eman-вирішення або не вирішення протиріч крізь надбання відкритої системи навчання, що спрямована на поповнення (формування мотивованих дій на безперервний професійний розвиток);

VI eman - методологічний етап (формування клінічного мислення, аналіз існування протиріч у стоматологіїі, як і в інших медичних спеціальностях);

VII eman - визначення кінцевого рівня знань (іспит, як частина державної атестації за системою "Крок 3. Стоматологія”, контроль засвоєння знань, отриманих під час навчання на кафедрі стоматології післядипломної освіти);

VIII- заключний етап - проведення науково-практичної конференції(вирішення проблемної ситуації під керівництвом викладача, формування власного світогляду у напрямку безперервного професійного розвитку);

$I X$ - визначення кінцевого рівня знань, умінь та навичок (іспит, як частина державної атестації при присвоєнні кваліфікації лікаря-стоматолога для лікарівінтернів, що навчалися в інтернатурі за спеціальністю "Стоматологія" ) [2].

Наші спостереження та аналіз результатів контролю навчання за системою "Крок 3. Стоматологія" носили довготривалий характер з 2007 року по 2012 рік-включно. В процесі розвитку педагогічної ідеї і перетворення ії на педагогічну концепцію ми переконалися, що самі технології навчання, як засоби, без створення умов у вигляді заходів для навчання були малоефективні, про що свідчили результати тестування у 2007 році (рис. 1. Діаграма 2007 року).

У подальшому ми поєднали оптимізацію заходів та засобів у навчанні лікарів-інтернів-стоматологів. Тобто процес оптимізації торкнувся не тільки технологій навчання, а й умов, в яких вони мають проводитися, організації процесу навчання, методичного забезпечення процесу навчання, управління процесом навчання. Відбулося підвищення результативності в системі знань, про що свідчив контроль навчання за системою “Крок 3. Стоматологія”. Крім того, можна було констатувати стабілізацію досягнутого результату протягом останніх трьох років, починаючи з 2010 року. На діаграмі відображено результати 2011 та 2012 років навчання лікарів-інтернів-стоматологів, які свідчили про 100 \% успішність. Слід відмітити, що “планка" поняття про успішність, порівняно із по- 


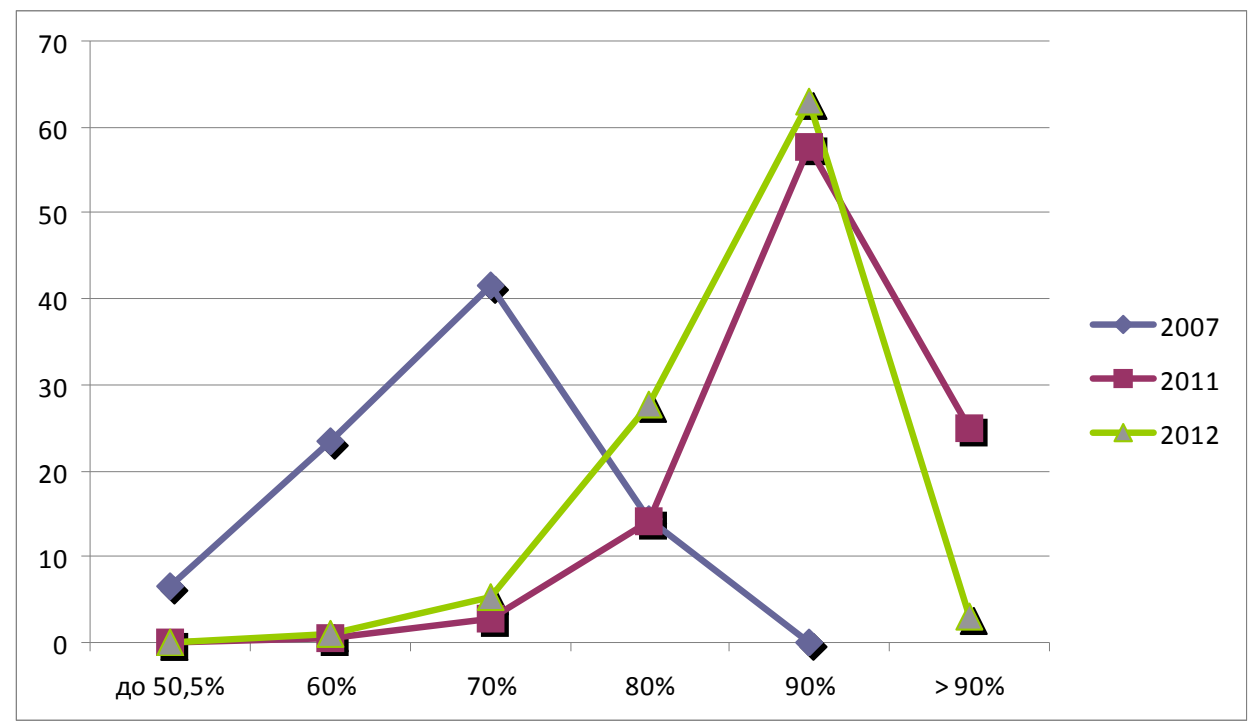

Puc. 1. Результати тестування лікарів-інтернів-стоматологів за системою “Крок 3. Стоматологія” у 2007 (на початку оптимізації навчання) та у 2011-2012 роках (при впровадженні методик оптимізації навчання та створенні умов їх застосування) на кафедрі стоматології ФПО ДВНЗ “ІФНМУ”.

передніми роками, у 2012 році була піднята з 50,5\% правильних відповідей до 55,5 \% (рис. 2). На діаграмі показана успішність кожного з 191 інтернів-стоматологів, що одночасно брали участь у тестуванні.
За теорією поетапного формування розумових дій, сама по собі інноваційна методика викладання при навчанні професійної фахової діяльності ще не визначає масовості засвоєння матеріалу та не сприяє фор-

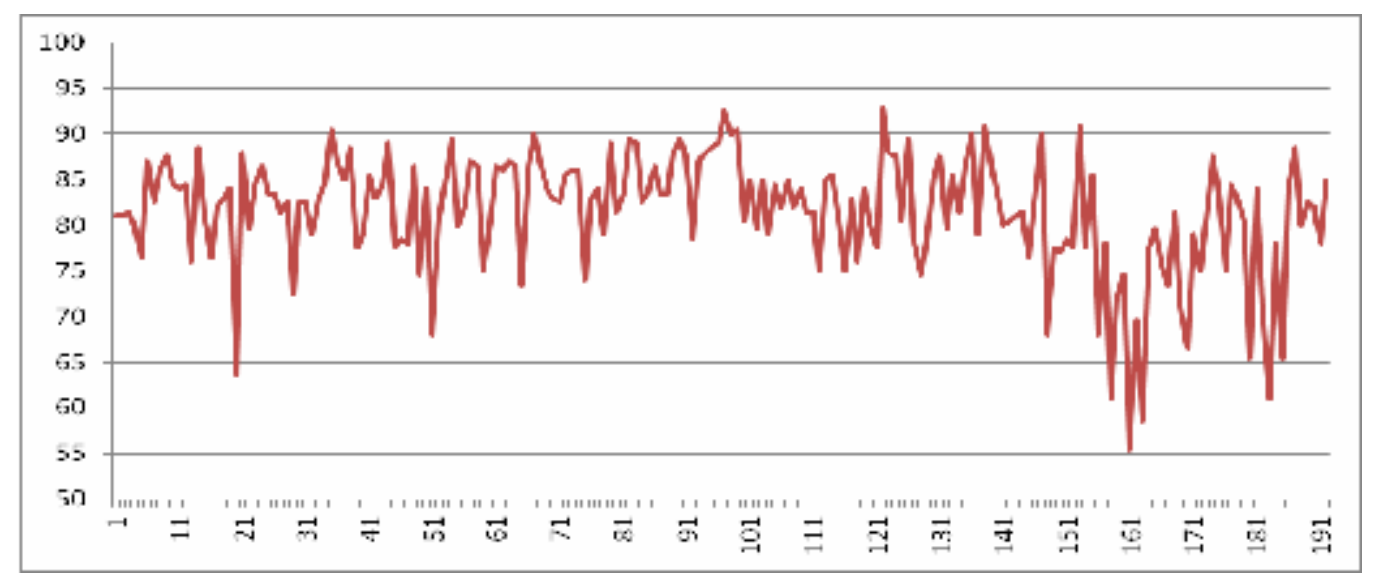

Puc. 2. Результати тестування лікарів-інтернів-стоматологів за системою “Крок 3. Стоматологія” у 2012 році (при впровадженні методик оптимізації навчання та створенні умов їх застосування) на кафедрі стоматології ФПО ДВНЗ “ІФНМУ”.

муванню у більшості тих, хто навчається, якості продукту навчання. Тобто методики навчання можуть бути найдосконалішими, але їх опанування здійснюється тільки певною категорією осіб, що навчаються. Про це яскраво свідчили результати “Кроку 3. Стоматологія" за 2007 рік (рис. 1. Діаграма 2007 року). На той час методики, як засоби подання навчального матеріалу для лікарів-інтернів-стоматологів на кафедрі стоматології ФПО ДВНЗ “ІФНМУ”, існували, але їх результативність була низькою (рис. 1. Діаграма 2007 р.).
Нами було доведено, що технології навчання, як засоби, без створення умов у вигляді заходів для навчання, були малоефективні. Для більш активної реалізації самостійної роботи лікарів-інтернів-стоматологів, в плані вдосконалення умінь та навичок, в педагогічному процесі доцільно додатково використовувати різні за оснащенням установи як державного, так і недержавного упорядкування із урахуванням юридичного супроводу, що являло собою зовнішній (за межами матеріальної бази кафедри) шлях оптимізації. 
Таким чином, один з видів категоріально-понятійного апарату педагогіки вищої школи - методологічний, може повноцінно розвиватися при розвитку педагогічних ідей та педагогічних концепцій, що існують одночасно та довготривало. При виконанні тими, хто навчається, $100 \%$ опанування знань за незалежним тестуванням протягом трьох років можна говорити про педагогічні закономірності оптимізації педагогічного процесу. В процесі розвитку педагогічної ідеї і перетворення її на педагогічну концепцію ми переконалися, що самі технології навчання, як засоби, без створення умов у вигляді заходів для навчання були малоефективні. Значно більша оптимізація педагогічного процесу на кафедрі стоматології ФПО ДВНЗ “ІФНМУ” відбувалася завдяки активізації ресурсів: адміністративного, кадрового, матеріального, фінансового, культурного, інформативного, інноваційного, що складають заходи. Іншими сучасними заходами, що використовувалися в педагогічному процесі, була співпраця державної установи з приватними структурами.

Висновки: 1. Дієвість основної методики навчання, що розроблена нами при підготовці лікарівінтернів-стоматологів, має бути забезпечена кропіткою роботою викладацького складу за наступними ресурсними складовими: адміністративними, кадровими, матеріальними, фінансовими, інноваційними, інформаційними та культурними, що являє собою

\section{Література}

1. Галузинський В. М. Основи педагогіки та психології вищої школи в Україні / В. М. Галузинський, М. Б. Свтух. К. : ІНТЕЛ, 1995. - 168 c.

2. Оптимізація навчального процесу у підготовці лікарівінтернів-стоматологів. (Повідомлення 4.) / С. В. Косенко, М. М. Рожко, 3. Т. Костишин [та ін.] // Галицький лікарський вісник. -2012. - Т. 19, число 1.-С. 117-118.

3. Мороз О. Г. Педагогіка і психологія вищої школи : навч. внутрішній (у межах кадрового складу кафедри) шлях оптимізації.

2. Для більш активної реалізації самостійної роботи лікарів-інтернів-стоматологів, в плані вдосконалення умінь та навичок, в педагогічному процесі доцільно додатково використовувати різні за оснащенням установи як державного, так і недержавного упорядкування із урахуванням юридичного супроводу, що являє собою зовнішній (за межами матеріальної бази кафедри) шлях оптимізації.

3. Застосування методик як засобів навчання в інтернатурі при підготовці лікарів-інтернів-стоматологів та процес управління навчанням як заходи для професійного навчання здатні значно покращити результати іспиту за системою "Крок 3. Стоматологія”, і звести відсоток лікарів-інтернів-стоматологів, які не справилися із завданням, до $0 \%$.

4. Методики навчання, як засоби навчання лікарівінтернів- стоматологів, найбільш ефективно здатні впливати на процес оптимізації навчання, якщо їх дія забезпечена шляхами оптимізації, як заходами навчання: зовнішнім (за межами матеріальної бази кафедри) та внутрішнім (у межах кадрового складу кафедри).

5. Засоби та заходи навчання складають методологічне забезпечення процесу навчання лікарівінтернів-стоматологів, що приводить до оптимізації процесу навчання та якості навчання значної кількості тих, хто навчається.

посіб. для молодих викладачів, аспірантів і майбутніх магістрів / Національний педагогічний ун-т ім. М. П. Драгоманова / О. Г. Мороз, О. С. Падалка, В. І. Юрченко; Інститут вищої освіти АПН України / О. Г. Мороз (заг. ред.). -К. : НПУ, 2003. $-267 \mathrm{c}$.

4. Подшивалкіна В. І. Методика розробки тестів об’єктивного контролю рівня освітньо-професійної підготовки студентів вузів / В. І. Подшивалкіна. - Херсон, 2008. - 36 с. 